\title{
TEMPERATURE AND ACCUMULATION OF HIGH ALTITUDE FIRN \\ IN THE ALPS
}

\author{
by \\ WIIFRIED HaEbERLI AND JÜRg ALEAN \\ Versuchanstalt für Wasserbau, Hydrologie und Glaziologie, \\ ETH-Zentrum, CH-8092 Zürich, Switzerland
}

\begin{abstract}
Data on temperature and accumulation of high altitude firn in the Alps are compiled and discussed. Firn temperature varies with incoming radiation (slope aspect) at a given altitude. The altitudinal gradient of temperature in highly permeable firn bodies appears to be about twice as high as the mean lapse rate of air temperature. "Cold infiltration" takes place above about $3500 \mathrm{~m}$ a.s.l. Firn temperatures on the highest peaks are around $-15^{\circ} \mathrm{C}$. Accumulation (net balance) also decreases with increasing altitude from about $3 \mathrm{~m} \mathrm{H}_{2} \mathrm{O}$ at $3500 \mathrm{~m}$ a.s.l. to around $0.5 \mathrm{~m} \mathrm{H}_{2} \mathrm{O}$ at wind exposed sites between 4300 and $4800 \mathrm{~m}$ a.s.l. Probably this is strongly due to wind erosion and topographical effects. However, temperature and accumulation not only appear to be interrelated, but also seem to be positively correlated to the heat applied to the surface. Assuming the observed altitudinal gradients have remained constant in time, it can be estimated that high altitude firn bodies have become considerably warmer since the last century. $\mathrm{CO}_{2}$-induced atmospheric warming could lead to a drastic change in the mass turnover and flow activity of high glaciers, in wind-exposed places where wind erosion of the snowpack becomes a controlling factor of accumulation.
\end{abstract}

\section{INTRODUCTION}

Studies on mass and heat exchange at the surface of alpine firn have usually been carried out at altitudes below about $3500 \mathrm{~m}$ a.s.l., where firn is temperate and accumulation is high (eg Lang and others 1977, Müller 1977). Access to firn regions of higher altitudes is difficult. However, rather unusual construction work (eg Refuge Jenkins on Mont Blanc), and a number of tunnels dug into the firn of the Monte Rosa region by J E Fisher in the 1950s, furnished some information which indicated that at high altitudes, firn is cold and accumulation does not further increase with altitude.

Interest in temperature and accumulation of high altitude firn has grown recently in connection with (1) englacial temperatures, (2) ice avalanches, and (3) alpine core drilling. Temperature distribution in the tongue of Grenzgletscher, one of the largest ice bodies in the Alps, must be caused by advection of cold ice from high altitudes (Blatter and Haeberli 1984). The frequency of ice avalanches ultimately depends on the accumulation of firn (Alean 1985), and the stability of steep mountain glaciers seems to depend on firn and ice temperatures (Röthlisberger 1981, Alean 1984). Finally, core drilling projects in cold, high alpine firn and ice provide important information about the evolution of the composition of the atmosphere in heavily industrialized regions over past decades and centuries (eg Wagenbach and others in press), but require knowledge about the distribution of accumulation in space and time.

The aims of the present study are to compile information available and point to possible effects of recent atmospheric warming.

\section{FIRN TEMPERATURE}

Temperature measurements from deep pits, tunnels, and shallow bore-holes in high altitude firn of the Alps have been compiled by Haeberli (1976, cf also Hooke and others 1983). New information is available from Chli Titlis, Jungfraujoch/Sphinxgrat and Monte Rosa/Colle Gnifetti (all Swiss Alps). At Chli Titlis, 3070 $\mathrm{m}$ a.s.l., $15 \mathrm{~m}$-temperature in the summit's $22 \mathrm{~m}$ thick firn and ice was $-0.7^{\circ} \mathrm{C}(1979 / 80$, cf. Haeberli and others 1979). Temperatures in the Sphinxgrat crest were measured in a $70 \mathrm{~m}$ borehole through firn, ice and perennially frozen rocks, in connection with recent construction work at the Jungfraujoch. The ice-rock interface, $10 \mathrm{~m}$ below the surface at $3525 \mathrm{~m}$ a.s.l. had a temperature close to $-6^{\circ} \mathrm{C}(1981)$. Temperatures around $-14^{\circ} \mathrm{C}$ at $15 \mathrm{~m}$ depth were registered in all core drilling boreholes made so far on Colle Gnifetti ( $4450 \mathrm{~m}$ a.s.1.) The firn-ice transition in this cold firn saddle occurs about $40 \mathrm{~m}$ below the surface (Schotterer and others 1981).

When presently-known firn temperatures are compiled (Figure 1) two groups seem to exist. Group 1 incorporates summits, crests and probably also very steep slopes $\left(\geqslant 45^{\circ}\right)$ which mainly consist of impermeable ice or high density firn with high concentrations of ice layers. Temperatures in such ice bodies decrease with increasing altitude at a rate (about $1^{\circ} \mathrm{C} / 100 \mathrm{~m}$ ) which is slightly higher than the assumed lapse rate of mean annual air temperature $\left(0.65^{\circ} \mathrm{C} / 100 \mathrm{~m}\right)$. No temperate firn bodies are known in such situations. In contrast, more gentle slopes and basins (group 2) where highly permeable firn accumulates, are temperate up to about $3600 \mathrm{~m}$ a.sl Above this upper boundary of the "warm infiltration zone" of the Alps, percolating meltwater cannot

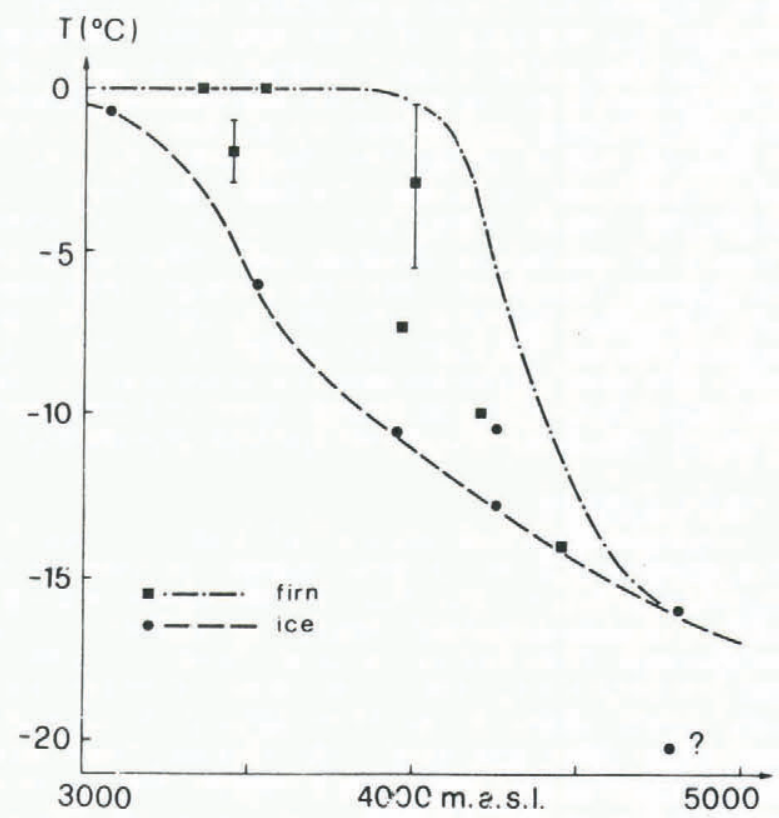

Fig.1. Temperature ( $\mathrm{T}$ ) of high altitude firn and ice in the Alps (10 to $20 \mathrm{~m}$ depth). Cf text and Haeberli (1976) for references. The curved lines are envelopes. 
completely warm up the firn bodies any more. Here in the "zone of cold infiltration" (Shumskii 1964), firn temperatures decrease with altitude at a rate which is at least twice the lapse rate of mean annual air temperature. At Colle Gnifetti, refrozen melt layers are commonly observed in snow layers which have been deposited during the same year (infiltration/recrystallization), and in some years no melt layers may form at all (dry snow zone). Melt layer formation is the exception rather than the rule on top of Mont Blanc, the highest point in the Alps. Mean firn temperature there is very close to the mean air temperature.

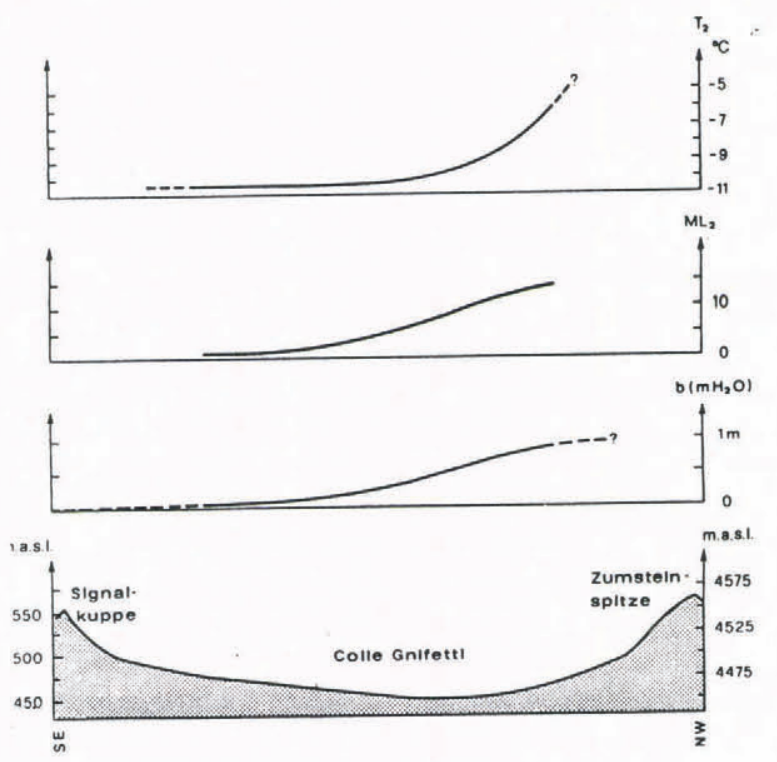

Fig.2. Near-surface firn temperature $\left(T_{2}\right.$, summer 1980), number of refrozen melt layers within the top $2 \mathrm{~m}\left(\mathrm{ML}_{2}\right.$, summer 1981), net balance (b, 1980/81), and topography on Colle Gnifetti/Monte Rosa (data from Alean and others 1983).

Detailed observations within a stake network around the core drilling site on Colle Gnifetti, Monte Rosa, throw more light on the connection between the variability of firn temperature and accumulation at a given altitude (cf Alean and others 1983). Figure 2 illustrates the variability of some important parameters across the firn saddle which is exposed to strong winds, predominantly from the west. Firn temperature increases towards the sunny side of the $\mathrm{col}$, as does the amount of available radiant energy and the number of refrozen melt layers. At a given altitude, therefore, firn temperature (local variability \pm 2 to $4^{\circ} \mathrm{C}$ ) seems primarily to depend on incoming solar radiation (slope and aspect). Latent heat exchange through percolating and refreezing meltwater thereby appears to be an important factor. However, the relation between energy input, melt layer formation and firn temperature is less clear than expected, because energy input and melt layer formation also seem to be correlated with accumulation.

\section{ACCUMULATION}

Accumulation (net balance) at high altitudes has been determined in only a small number of cases up to now. Figure 3 is a compilation of information available from Jungfraufirn/Aletschglacier (Aellen and Röthlisberger 1981) and the Southern Hanging Glacier of Mänch (Alean 1985), from Jungfraujoch (Ambach 1969), from several places in the Mont Blanc area (Lliboutry and others 1976) and from Colle Gnifetti/Monte Rosa (Alean and others 1983). Below about $3500 \mathrm{~m}$ a.s.1. accumulation usually increases with increasing altitude because of higher amounts of solid precipitation and less melting. The highest mean accumulation rates in the Alps (around $3 \mathrm{~m} \mathrm{H}_{2} \mathrm{O}$ ) have been measured at 3500 to

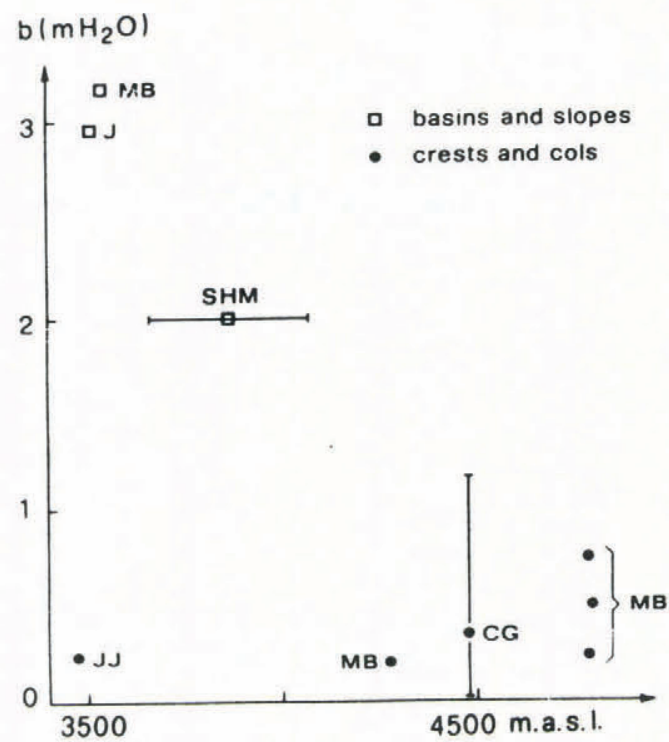

Fig.3. Accumulation (net balance) of high altitude firn in the Alps. CG $=$ Colle Gnifetti; $\mathrm{J}=$ Jungfraufirn $/$ Aletsch
glacier; JJ = Jungfraujoch; $\mathrm{MB}=$ Mont Blanc; SHM = Southern Hanging Glacier of Mönch.

$3550 \mathrm{~m}$ a.s.l. (Jungfraufirn and Vallée Blanche/Mont Blanc). At even higher altitudes, considerably smaller accumulation rates were observed. Values in the order of $0.5 \mathrm{~m} \mathrm{H}_{2} \mathrm{O}$ seem most common at 4300 to $4800 \mathrm{~m}$ a.s.l.

Extreme local variability of accumulation rates can be observed at a given altitude. A detailed study around Colle Gnifetti core drilling site (Figure 2, cf Alean and others 1983) indicates that melt layers protect the snow from wind erosion and that energy input and melt layer formation are probably positively correlated with net balance at wind exposed sites. In 1980/81, net balance on Colle Gnifetti varied between almost 0 in north exposed positions to more than $+1 \mathrm{~m}_{2} \mathrm{O}$ on the sunny slope. In the following year probably only negative balance values occurred. This pronounced variability of accumulation is certainly due to wind effects and snowdrift. Accumulation rates are lower on wind-exposed crests and saddles than in protected places (slopes and basins), the latter becoming rare at very high altitudes. This may explain a major part of the decrease of accumulation with altitude above about $3500 \mathrm{~m}$ a.s.1.

\section{DISCUSSION AND CONCLUSIONS}

Despite the great scatter of the measured values, there appears a clear tendency for firn temperature and accumulation to decrease with altitude above the upper boundary of the "warm infiltration zone" in the Alps. In the case of firn temperatures, this altitudinal change can easily be assumed to be mainly the effect of decreasing air temperature (mainly by latent heat exchange from percolating and refreezing meltwater). The reasons for the decrease of accumulation with altitude are probably more complex. High wind speeds and a less suitable topography around mountain peaks certainly have an important influence. However, a temperature effect is also likely to exist, because cold and dry snow at high altitudes is more easily eroded by wind than temperate firn containing refrozen melt layers. This means that the temperature and accumulation of firn at high altitudes could be interrelated to some degree, and that both could be positively correlated to the heat applied to the surface. Similar observations are known from polar regions (Loewe 1970; Herron and Langway 1980).

It remains difficult to reach a better understanding of the complex processes and interactions behind the observed phenomena until more detailed information is available. However, the obvious influence of air temperature on firn temperature and probably even on accumulation might lead to speculations about developments in time. Mean annual air temperature has 
risen by about 0.5 to $1.0^{\circ} \mathrm{C}$ in the Alps since the last century (Rudloff 1980). Correspondingly, temperature of high altitude firn bodies may have increased by about 1 to $2{ }^{\circ} \mathrm{C}$. A continuation or even acceleration of this trend (eg, as a consequence of $\mathrm{CO}_{2}$-induced atmospheric warming) could raise firn temperatures by several degrees within a few decades and shift altitudinal belts such as the "zone of warm infiltration" by several hundred meters. If accompanied by a corresponding increase in accumulation rates, such a development would lead to a considerable change of mass turnover and activity of high altitude ice bodies in the Alps. However, since the processes involved are complex and only few data are available, firm conclusions are difficult to draw.

\section{ACKNOWLEDGEMENTS}

Prof. Dr. H. Röthlisberger critically read the manuscript. Pamela Alean helped prepare the text and Werner Nobs drew the diagrams.

\section{REFERENCES}

Aellen M, Röthlisberger H 1981 Gletschermessungen auf Jungfraujoch. In Kantonalbank von Bern (ed) 50 Jahre Hochalpine Forschnungsstation Jungfraujoch. Bulletin 23: 82-92

Alean J 1985 Ice avalanche activity and mass turnover of a high altitude hanging glacier in the Swiss Alps. Annals of Glaciology this volume

Alean J 1984 Untersuchungen über Entstehungsbedingun gen und Reichweiten von Eislawinen. Mitteilung der Versuchsanstalt fur Wasserbau, Hydrologie und Glaziologie der ETH Zurich, Nr 74

Alean J, Haeberli W, Schädler B 1983 sow accumulation, firn temperature and solar radiation in the area of the Colle Gnifetti core drilling site (Monte Rosa, Swiss Alps): distribution patterns and interrelationships. Zeitschrift fur Gletscherkunde und Glazialgeologie XIX(2): 131-147

Ambach W, Eisner H, Sauzay G 1969 Tritium profiles in two firn cores from Alpine glaciers and tritium content in precipitation in the Alpine area. Archiv für Meteorologie, Geophysik und Bioklimatologie B 17: 93-104

Blatter H, Haeberli W 1984 Modelling temperature distribution in Alpine glaciers. Annals of Glaciology 5: $18-22$

Haeberli W 1976 Eistemperaturen in den Alpen. Zeitschrift für Gletscherkunde und Glazialgeologie XI(2): 203-220

Haeberli W, Iken A, Siegentaler H 1979 Glaziologische Aspekte beim Bau der Fernmelde-Mehrzweckanlage der PTT auf dem Chli Titlis. Mitteilung der Versuchsanstalt für Wasserbau, Hydrologie und Glaziologie der ETH Zurich 41:59-75

Hooke R le B, Gould J E, Brzozowski J 1983 Near surface temperatures near and below the equilibrium line on polar and subpolar glaciers. Zeitschrift für Gletscherkunde und Glazialgeologie XIX(1): $1-25$

Herron M M, Langway C C 1980 Firndensification: an empirical model. Journal of Glaciology 25(93): 373-385

Lang H, Schädler B, Davidson G 1977 Hydroglaciol ogical investigations on the Ewigschneefeld (Gr. Altetschgletscher). Zeitschrift fur Gletscherkunde und Glazialgeologie XII(2): 109-124

Lliboutry L. Briat M, Creseveur M, Pourchet M 1976 $15 \mathrm{~m}$ deep temperatures in the glaciers of Mont Blanc (French Alps). Journal of Glaciology 16(74): 197-204

Loewe F 1970 Screen temperatures and $10 \mathrm{~m}$ temperatures. Journal of glaciology 9(56): 263-268

Müller F 1977 Fluctuations of glaciers 1970-1975 (Volume III) IAHS (ICSI)-UNESCO, Paris

Röthlisberger H 1981 Eislawinen und Ausbrüche von Gletscherseen. Jahrbuch der Schweizerischen Naturforschenden Gesellschaft, wissenschaftlicher Teil 1978: $170-212$

Rudloff H v 1980 Die Klima-Entwicklung in den letzten Jahrunderten im mitteleuropäischen Raume (mit einen Rückblick auf die postglaziale Periode). In Oeschger H, Messerli B, Svilar M (eds) Das Klima, Springer Verlag, Berlin: $125-148$
Shumskii P A 1964 Principles of structural glaciology. New York, Dover Publications

Schotterer U, Haeberli W, Good W, Oeschger H, Röthlisberger H 1981 Datierung von kaltem Firn und Eis in einem Bohrkern vom Colle Gnifetti, Monte Rosa. Jahrbuch der Schweizerischen Naturforschenden Gesellschaft, wissenschaftlicher Teil 1978: 48-57

Wagenbach D, Gorlach U, Haffa K, Junghans H G, Münnich $\mathrm{K} O$, Schotterer $\mathrm{U}$ in press $\mathrm{A}$ longterm aerosol deposition record in a high altitude Alpine glacier. WMO Technical Conference on Observation and Measurement of Atmospheric Contaminants (TECOMAC) Vienna 1983 